\title{
Progressivity of personal income tax in Croatia: decomposition of tax base and rate effects
}

Urban, Ivica

Source / Izvornik: Occasional Paper Series, 2007, 11, 1 - 33

Journal article, Published version

Rad u časopisu, Objavljena verzija rada (izdavačev PDF)

https://doi.org/10.3326/ops.32

Permanent link / Trajna poveznica: https:/urn.nsk.hr/urn:nbn:hr:242:394546

Rights / Prava: Attribution-NonCommercial-NoDerivatives 4.0 International/ImenovanjeNekomercijalno-Bez prerada 4.0 međunarodna

Download date / Datum preuzimanja: 2023-04-26

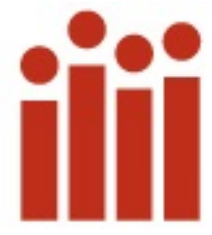

Institute of Public Finance Repository

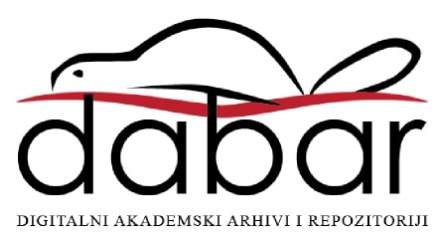




\section{PROGRESSIVITY OF PERSONAL INCOME TAX IN CROATIA: \\ DECOMPOSITION OF TAX BASE \\ AND RATE EFFECTS}

Ivica Urban

Occasional Paper No. 32

December 2006 


\title{
PROGRESSIVITY OF PERSONAL INCOME TAX IN CROATIA: DECOMPOSITION OF TAX BASE AND RATE EFFECTS*
}

Ivica Urban

Institute of Public Finance, Zagreb

ivica@iif.hr

\begin{abstract}
This paper presents progressivity breakdowns for Croatian personal income tax (henceforth PIT) in 1997 and 2004. The decompositions reveal how the elements of the system - tax schedule, allowances, deductions and credits - contribute to the achievement of progressivity, over the quantiles of pre-tax income distribution. Through the use of 'single parameter' Gini indices, the social decision maker's (henceforth SDM) relatively more or less favorable inclination toward taxpayers in the lower tails of pre-tax income distribution is accounted for. Simulations are undertaken to show how the introduction of a flat-rate system would affect progressivity.
\end{abstract}

JEL Classification: $\mathrm{H} 23, \mathrm{H} 24$

Keywords: personal income tax, progressivity, decomposition

\footnotetext{
*This article is published in Croatian in the journal "Financial Theory and Practice", 30(3), 2006, pp.205-231, and is downloadable in Croatian from: http://www.ijf.hr/FTP/2006/3/urban.pdf, and also in English from: http://www.ijf.hr/eng/FTP/2006/3/urban.pdf
} 


\section{TABLE OF CONTENTS}

1. Introduction

2. Methodology

$\begin{array}{ll}\text { 2.1. Progressivity measures } & 5\end{array}$

$\begin{array}{ll}2.2 \text { Elements that cause progressivity } & 7\end{array}$

$\begin{array}{ll}2.3 \text { Inequality indices } & 9\end{array}$

$\begin{array}{ll}\text { 3. Analysis } & 11\end{array}$

$\begin{array}{ll}\text { 3.1 Personal income tax in Croatia } & 11\end{array}$

$\begin{array}{ll}3.2 \text { Data } & 13\end{array}$

$\begin{array}{ll}\text { 3.3 Progressivity and redistributive effect } & 13\end{array}$

$\begin{array}{ll}3.4 \text { Progressivity decomposition } & 16\end{array}$

$\begin{array}{ll}3.5 \text { Further analysis: simulation } & 20\end{array}$

$\begin{array}{ll}\text { 4. Conclusion } & 23\end{array}$

$\begin{array}{ll}\text { References } & 25\end{array}$

$\begin{array}{ll}\text { APPENDIX } & 26\end{array}$ 


\section{PROGRESSIVITY OF PERSONAL INCOME TAX IN CROATIA: DECOMPOSITION OF TAX BASE AND RATE EFFECTS}

Ivica Urban ${ }^{* *}$

\section{INTRODUCTION}

The tax system is said to be progressive (proportional, regressive) when the marginal tax rate is greater than (equal to, less than) the average tax rate. Progressive (proportional, regressive) income tax system reduces (leaves unchanged, increases) income inequality. The interest in studying tax progressivity lies, among other things, in the welfare superiority of progressive tax over the equal-yield proportional tax. In other words, the former implies a smaller welfare reduction than the latter for the same amount of tax collected. In this paper we deal with how different components of the PIT system contribute to the achievement of overall progressivity. The methodology developed by Pfähler (1990) was later refined by Lambert (2001) and applied by Wagstaff and van Doorslaer (2001) in investigating the relative significance of various elements of the PIT system - tax schedule, allowances, deductions and tax credits - in determination of final progressivity in 15 OECD countries. The results showed that in some countries progressivity was derived almost solely from the tax schedule, allowances or tax credits, while in others some mixture of these elements was present. Deductions proved to have a negative influence on progressivity in most countries.

This paper presents the decomposition of progressivity for the Croatian PIT system in 1997 and 2004. Based on the above mentioned methodology, it introduces some novelties in its application: progressivity component patterns are analyzed over quantiles of the relevant pre-tax income distributions, while through the use of 'single parameter' Gini indices, the social decision maker's relatively more or less favorable inclination toward taxpayers in the lower tails of the pre-tax income distribution is also accounted for. The structure of the paper is as follows. In Section 2, the basic methodology underlying progressivity measurement is presented. Section 3 contains a short overview of Croatian PIT system development over the period from 1997 to 2004. It continues with the analysis of different progressivity effects and ends with a simulation of tax burdens, undertaken to show how the introduction of a flat-rate system would affect PIT progressivity. Section 4 concludes.

\section{METHODOLOGY}

\subsection{Progressivity measures}

Let $L_{X}(p)$ be the Lorenz curve of pre-tax income at quantile $p$. If income were equally distributed, each fraction $p$ of the population would have exactly $p \cdot 100$ percent of total pre-tax income. ${ }^{1}$

\footnotetext{
"I am grateful to three referees and to Peter J. Lambert for plenty of helpful comments on an earlier version of this paper.

On measurement of income inequality and redistribution see Lambert (2001) and Duclos and Araar (2006).
} 
However, they receive $L_{X}(p) \cdot 100$ percent of total pre-tax income, which is typically less than $p \cdot 100$ percent, and we may call the difference $p-L_{X}(p)$ an equality deficit. Analogously, we can define a Lorenz curve for post-tax income $L_{N}(p)$. Also, let $C_{T}(p)$ be the concentration curve for taxes and $C_{N}(p)$ the concentration curve for post-tax income ${ }^{2}$.

If the tax were proportional, each fraction $p$ of the population would pay exactly $L_{X}(p) \cdot 100$ percent of the total tax. However, they pay only $C_{T}(p) \cdot 100$ percent of the tax (which is typically less). We may call the difference $L_{X}(p)-C_{T}(p)$ a departure from proportionality. In the words of Lambert (2001) "the distance $L_{X}(p)-C_{T}(p)$ is that fraction of the total tax burden shifted from low incomes (the bottom $p \cdot 100$ percent) to high incomes (the top $(1-p) \cdot 100$ percent) by the presence of progression in the tax". If $L_{X}(p) \geq C_{T}(p)\left[L_{X}(p) \leq C_{T}(p)\right]$ for all values of $p$, with strict inequality holding at least somewhere, we say that the tax is progressive [regressive]. This approach to measurement yields what is called Tax-Redistribution (TR) progressivity (Pfähler, 1987). Thus, TR-progressivity of tax system measured at $p$-th quantile of the pre-tax income distribution is equal to:

$$
\pi^{T R}(p)=L_{X}(p)-C_{T}(p)
$$

We also adopt another approach, what is called Income-Redistribution (IR) progressivity. The $p \cdot 100$ percent of income units with the lowest pre-tax incomes own $L_{X}(p) \cdot 100$ percent of total pre-tax income, but $C_{N}(p) \cdot 100$ percent of total post-tax income (which is, typically, more). Therefore, $C_{N}(p)-L_{X}(p)$ shows the fraction of total post-tax income earned by the poorest $p \cdot 100$ percent income earners above their share in post-tax income that would occur under a proportional tax system. If $C_{N}(p) \geq L_{X}(p)\left[C_{N}(p) \leq L_{X}(p)\right]$ for all values of $p$, with strict inequality holding at least somewhere, again we say that the tax is progressive [regressive]. IR-progressivity of a tax system at the $p$-th quantile of pre-tax income distribution is equal to:

$$
\pi^{I R}(p)=C_{N}(p)-L_{X}(p)
$$

There is an important relationship between IR-progressivity and TR-progressivity, first introduced and proved by Kakwani (1977a, 1977b):

$$
\begin{aligned}
& \pi^{I R}(p)=\frac{t}{1-t} \pi^{T R}(p) \\
& C_{N}(p)-L_{X}(p)=\frac{t}{1-t}\left[L_{X}(p)-C_{T}(p)\right]
\end{aligned}
$$

\footnotetext{
${ }^{2}$ Notice the difference between a) Lorenz curve, which shows a proportion of total sum of the variable $K$ obtained by the $p \cdot 100$ percent of the population with the lowest values of $K$, and b) concentration curve, which shows a
} 
where $t$ stands for average tax rate. Kakwani's relationship tells us that a certain amount of income redistribution can be achieved either with higher TR-progressivity and a lower average tax rate, or vice versa. Assuming that the system is progressive and pre-tax income does not change, a proportionate increase (or decrease) of tax liabilities, would not affect TR-progressivity but would affect IRprogressivity. $^{3}$

\subsection{Elements that cause progressivity}

Let us now turn to the definition of the tax function. First, we define the tax base $B_{i}$ of individual $i$ as $B_{i}=X_{i}-A_{i}-D_{i}$, where $A_{i}$ represents individual i's total tax allowances, and $D_{i}$ represents deductions. The gross tax $G_{i}$ is a (typically) piecewise linear function of the tax base (though not so in Germany). The net tax $T_{i}$ is obtained as $G_{i}-C_{i}$, where $C_{i}$ denotes the tax credits of individual $i$. Allowances $(A)$ include basic allowance and additional allowances given according to the family-related or age-related characteristics of the taxpayer; in some countries they are also called 'basic personal exemptions'. Deductions (D) include proportionate deductions of income and expenditure-related items, such as mortgage interest payments, insurances, charities, etc.

Analogously to IR-progressivity, we may define four different IR-effects, one for each of the abovementioned elements:

a) the IR-progressivity of allowances, $\pi_{A}(p)$, measures disproportionality between the tax base $X-A$ that would occur if only allowances existed (i.e. in the absence of deductions), and pre-tax income, $X$ :

$$
\pi_{A}(p)=C_{X-A}(p)-L_{X}(p) \equiv \frac{a}{1-a}\left[L_{X}(p)-C_{A}(p)\right]
$$

b) the IR-progressivity of deductions, $\pi_{D}(p)$, measures disproportionality between the tax base $X-D$ that would occur if only deductions existed, and pre-tax income $X$ :

$$
\pi_{D}(p)=C_{X-D}(p)-L_{X}(p) \equiv \frac{d}{1-d}\left[L_{X}(p)-C_{D}(p)\right]
$$

C) the IR-progressivity of the rate structure, $\pi_{R}(p)$, measures disproportionality between the actual tax base, reduced by gross tax $(X-A-D-G)$, and tax base $(X-A-D)$ itself:

proportion of total sum of the variable $L$ obtained by the $p \cdot 100$ percent of the population with the lowest values of $K$.

${ }^{3}$ If the tax system does not rerank individuals in the transition from the pre-tax to the post-tax income distribution, the concentration curve and Lorenz curve for post-tax income will coincide. However, in practice this is rarely the case, and therefore we also need to measure the reranking effect, $\pi^{R R}(p)=C_{N}(p)-L_{N}(p)$, as the departure from a horizontally neutral tax system, which can also be interpreted as a loss of potential redistribution. Finally, we can define the redistributive effect, $\pi^{R E}(p)=L_{N}(p)-L_{X}(p)$, which is comprehensive in the sense that it accounts both for potential redistribution and the loss due to reranking: $\pi^{R E}(p)=\pi^{I R}(p)-\pi^{R R}(p)$. 


$$
\pi_{R}(p)=C_{X-A-D-G}(p)-C_{X-A-D}(p) \equiv \frac{g}{1-a-d-g}\left[C_{X-A-D}(p)-C_{G}(p)\right]
$$

d) the IR-progressivity of tax credits, $\pi_{C}(p)$, measures disproportionality between pre-tax income augmented by tax credits $(X+C)$ and pre-tax income itself $(X)$ :

$$
\pi_{C}(p)=-C_{X+C}(p)+L_{X}(p) \equiv \frac{c}{1+c}\left[L_{X}(p)-C_{C}(p)\right]
$$

Based on principles laid down by Pfähler (1990), Lambert (2001) developed a methodology for breaking down TR- and IR-progressivity into components that explain the contributions of the rate schedule, allowances and deductions to overall progressivity. In this paper the decomposition of IR-progressivity will be used, extended to cover also tax credits. The decomposition formula is a weighted average of the progressivity terms defined above:

$$
\pi^{I R}(p)=\frac{g}{1-g+c}\left[\frac{b-g}{g} \pi_{R}(p)-\frac{1-a}{b} \pi_{A}(p)-\frac{1-d}{b} \pi_{D}(p)\right]-\frac{1+c}{1-g+c} \pi_{C}(p)
$$

where $g, a, d, c$ and $b$ are respectively the shares of gross tax, allowances, deductions, tax credits and the tax base in total pre-tax income $X .{ }^{4}$ For practical reasons, the terms $\pi_{A}(p)$ and $\pi_{C}(p)$ are replaced (in Lambert (2001), followed also by Wagstaff and van Doorslaer (2001)) by their negative counterparts, $\rho_{A}(p)=-\pi_{A}(p)$ and $\rho_{C}(p)=-\pi_{C}(p)$, which are respectively called "regressivities" of allowances and tax credits. Here we do the same, and (8) becomes:

$$
\pi^{I R}(p)=\frac{g}{1-g+c}\left[\frac{b-g}{g} \pi_{R}(p)+\frac{1-a}{b} \rho_{A}(p)-\frac{1-d}{b} \pi_{D}(p)\right]+\frac{1+c}{1-g+c} \rho_{C}(p)
$$

The first term on the right hand side of (8b) presents the contribution to IR-progressivity of the gross tax liability, whereas the second term reveals the portion of progressivity attributable to tax credits. Although they are obvious from equation (8b), for easier reference later we will now identify the following quantile measures, to describe the contributions of the following four elements to overall IRprogressivity: the rate structure effect, the allowance effect, the deductions effect, and the tax credit effect (9):

$$
\begin{aligned}
& E_{R}^{I R}(p)=\frac{g}{1-g+c} \frac{b-g}{g} \pi_{R}(p), E_{A}^{I R}(p)=\frac{g}{1-g+c} \frac{1-a}{b} \rho_{A}(p), \\
& E_{D}^{I R}(p)=-\frac{g}{1-g+c} \frac{1-d}{b} \pi_{D}(p), E_{C}^{I R}(p)=\frac{1+c}{1-g+c} \rho_{C}(p)
\end{aligned}
$$

\footnotetext{
${ }^{4}$ Note that the average net tax rate, $t$, is equal to $t=g-c$. Throughout the text the term "average tax rate" is synonymous with "average net tax rate".
} 


\subsection{Inequality indices}

So far, we have measured progressivity effects as distances between relevant Lorenz and concentration curves at different quantiles of the income distribution. To obtain aggregate measures of progressivity, these distances can be summed up using any desired weighting scheme. One such scheme, $w(p)$, gives different weights to distances occurring at different quantiles of the distribution, thus expressing the ethical attitudes of the observer. This type of scheme, first proposed by Mehran (1976), gives us a family of linear inequality indices, I :

$$
I_{X}=\int_{0}^{1}\left[p-L_{X}(p)\right] w(p) d p
$$

The index in (10) represents inequality of pre-tax income. However, the term $p-L_{X}(p)$ in (10) can be replaced by any one of the rank differences mentioned above. In the analysis that follows, we concentrate on one special case, that of the so-called single parameter Gini indices of inequality by Donaldson and Weymark (1980), for which the weights are defined as follows:

$$
w(p)=\kappa(p, v)=v(v-1)(1-p)^{(v-2)}
$$

where $v \geq 1$. These weights are illustrated in Figure 1 for several values of the ethical parameter $v$. Observe several cases:

a) $v=1 \rightarrow \kappa(p, v)=0$ for every $p \rightarrow I_{X}=0 \rightarrow$ no inequality is observed, whatever the distribution of incomes.

b) $v=2 \rightarrow \kappa(p, v)=2$ for every $p \rightarrow I_{X}=G_{X}$, where $G_{X}$ represents the standard Gini coefficient.

c) $1<v<2 \rightarrow \kappa(p, v)$ is increasing in $p$ giving larger ethical weights to equality deficits felt at higher $p s$.

d) $v>2 \rightarrow \kappa(p, v)$ is decreasing in $p$ thus giving larger ethical weights to equality deficits felt at lower ps.

Our single parameter measure of inequality, or S-Gini coefficient for pre-tax income, is defined as follows:

$$
G_{X}(v)=\int_{0}^{1}\left[p-L_{X}(p)\right] \kappa(p, v) d p
$$

Analogously to (12), from (1) and (2) we obtain the indices of TR- and IR-progressivity:

$$
\pi^{T R}(v)=\int_{0}^{1}\left[L_{X}(p)-C_{T}(p)\right] \kappa(p, v) d p ; \pi^{I R}(v)=\int_{0}^{1}\left[C_{N}(p)-L_{X}(p)\right] \kappa(p, v) d p
$$


Similarly, from (9) indices of the rate structure effect, $E_{R}^{I R}(v)$, the allowance effect, $E_{A}^{I R}(v)$, deductions effect, $E_{D}^{I R}(v)$, and tax credit effect, $E_{C}^{I R}(v)$, are obtained. Henceforth, we refer to all of these indices, which are based upon the S-Gini index of income inequality, as S-indices (of progressivity and its components). ${ }^{5}$

Figure 1 Weights for calculation of single-parameter indices

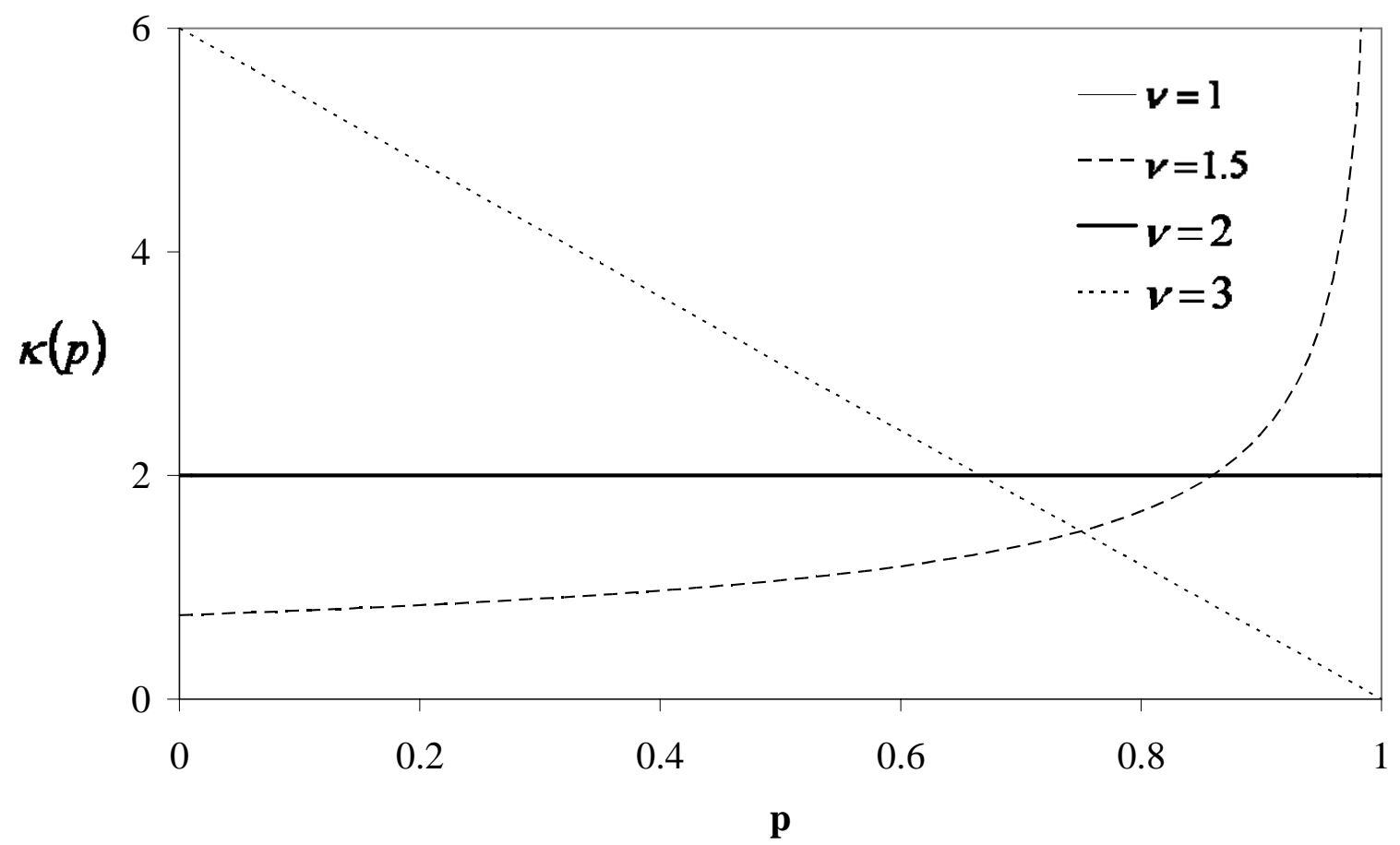

In the introduction it was said that progressivity is related to social welfare. Here we show that a progressive tax delivers more social welfare than an equal-yield proportionate tax; or put differently, the progressive tax can collect more revenue for identical social welfare than a proportionate tax. Denote with $W_{X}, W_{N}, W_{N}^{P, E T Y}$ and $W_{N}^{P, E S W}$ the social welfare ${ }^{6}$ values associated with the pre-tax income distribution, post-tax income distribution, distribution of income after the equal-yield proportional income tax and distribution of income after the proportional income tax that yields the same social welfare as actual post-tax income distribution.

$$
\begin{aligned}
W_{X} & =\mu\left[1-G_{X}\right], W_{N}=\mu(1-t)\left[1-G_{N}\right], \\
W_{N}^{P, E T Y} & =\mu(1-t)\left[1-G_{X}\right] ; W_{N}^{P, E S W}=\mu\left(1-t^{P, E S W}\right)\left[1-G_{X}\right]
\end{aligned}
$$

where $\mu$ is the mean pre-tax income, $t$ is actual average tax rate and $t^{P, E S W}$ is proportional tax rate that would achieve the same social welfare as the actual post-tax income distribution. It can be seen (Lambert, 2001, and similarly in Duclos et al, 2003) that:

$$
W_{N}-W_{N}^{P, E T Y}=\mu(1-t) \pi^{I R}
$$

\footnotetext{
${ }^{5}$ Duclos and Tabi (1995) apply S-Gini indices for measuring distribution and redistribution of income in Canada.

${ }^{6}$ See Appendix B on measurement of social welfare.
} 
Thus, if income tax is progressive $\left(\pi^{I R}>0\right)$, it will cause a smaller reduction of social welfare in the transition from pre-tax to post-tax income than an equal-yield proportional tax. We can express this welfare premium more suitably in terms of $W_{N}^{P, E T Y}$, and obtain the Blackorby-Donaldson index of inequality ${ }^{7}$ :

$$
\pi^{B D}=\frac{W_{N}-W_{N}^{P, E T Y}}{W_{N}^{P, E T Y}}=\frac{\pi^{I R}}{1-G_{X}}
$$

Similarly, from (14) we can obtain an index of tax revenue premium ${ }^{8}\left(\pi^{T R P}\right)$ that shows us, in terms of pre-tax income, how much more tax revenue can be collected due to progressivity compared to an identical-welfare proportional tax:

$$
\pi^{T R P}=t-t^{P, E S W}=\frac{(1-t) \pi^{I R}}{1-G_{X}}
$$

\section{ANALYSIS}

\subsection{Personal income tax in Croatia}

New PIT legislation that replaced the system inherited from the ex-socialist state was introduced in 1994. The tax schedule consisted of two brackets, and the corresponding rates were $20 \%$ and $35 \%$. Taxable income included wages and salaries, pensions, income from self-employment and rents. In 2001 there came several major changes: a) dividends were included into taxable income ${ }^{9}$; b) the use of separate schedules for some sorts of income was allowed; c) a number of deductions and special allowances were introduced for certain groups of taxpayers. The tax schedule was also changed, to contain three brackets, with corresponding tax rates of $15 \%, 25 \%$ and $35 \%$. In 2003 new reliefs were introduced, together with a fourth bracket with a rate of $45 \%$. More detailed description of the system is given in Table 1.

Table 1 Basics of PIT system in Croatia

Personal Allowance

1997

1. Basic: 9,600 kuna (all except pensioners); 24,000 kuna (pensioners)

2. For dependents: 2,900 kuna (one child); 6,700 kuna (two children); etc.

2004

1. Basic: 18,000 kuna (all except pensioners); 30,600 kuna (pensioners)

2. For dependents: 7,560 kuna (one child); 18,180 kuna (two children); etc.

\footnotetext{
${ }^{7}$ Blackorby and Donaldson (1984).

${ }^{8}$ Created for purposes of subsequent analysis in this paper.

${ }^{9}$ Dividends are excluded from taxation by the Law from 2005.
} 


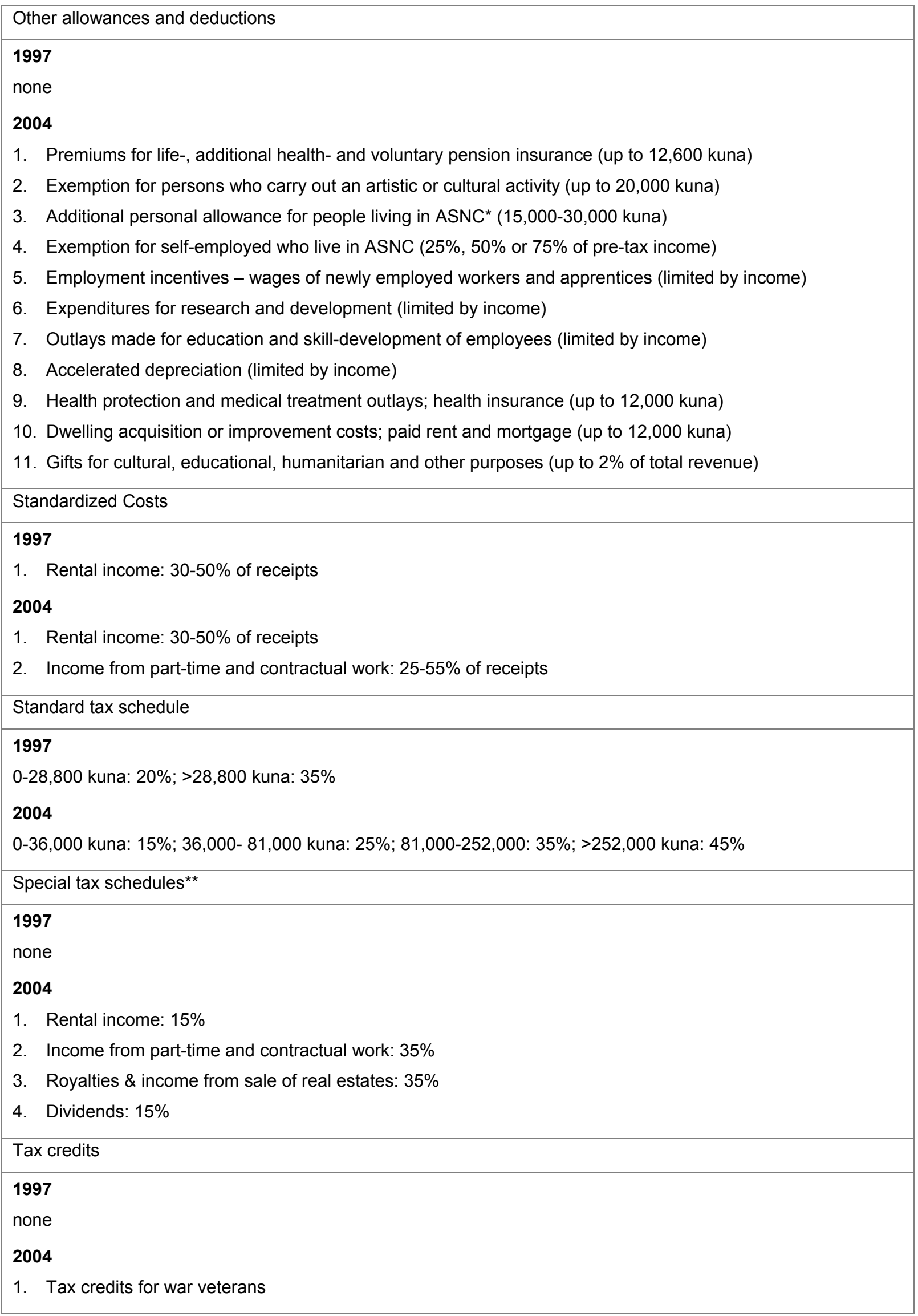

* ASNC - the areas of special national concern

${ }^{\star *}$ Final withholding 
Personal allowances consist of a basic allowance (BA), and an additional allowance for dependents (DA). Throughout the whole period, BA grew faster than average income, and dependent allowance factors ${ }^{10}$ were also increased. A specific characteristic of the PIT system in all years is that for pensioners a separate basic allowance was set, at a level almost twice as high as that of the general BA. The consequence is that only one in ten pensioners actually pay PIT; pensioners made up $33 \%$ (40\%) of the whole population of PIT payers in 1997 (2004). Whereas they held 19\% (27\%) of total income, they contributed less than $2 \%$ of the total tax revenue in both years. Because of this dual treatment of taxpayers, and since a significant increase in the number of pensioners occurred over the period due to early retirement, it was decided to perform separate analyses for two samples: one excluding pensioners, and another in which all taxpayers are covered.

In the following analysis, under the term allowances (A) we consider the sum of BA and DA. Obligatory contributions to the social security funds are not a part of income subject to taxation, and therefore they were not analyzed. Deductions (D) capture all other reliefs that reduce the tax base, shown in Table 1 under "other allowances and deductions" and "standardized costs". Among tax credits (C), there was only one such relief, in 2004, but it was negligible in amount. The tax unit is the individual. For purposes of comparability across years, income from dividends has been excluded from the analysis. ${ }^{11}$

\subsection{Data}

As part of a research project on redistributional aspects of the Croatian personal income tax and social security contributions, databases for personal income in 1997-2004 have been compiled. ${ }^{12}$ They are 4.3-5\% representative samples from the respective populations of PIT payers, containing, for each taxpayer: gross income by source, social security contributions paid by the employee, personal income tax paid, and the amounts of allowances and deductions. The following analysis draws upon these databases, which, after (before) exclusion of pensioners, contained data for 68,552 $(102,555)$ and $71,421(119,344)$ taxpayers in 1997 and 2004, respectively.

\subsection{Progressivity and redistributive effect}

Figure 2 shows TR- and IR-progressivity measures for Croatian PIT in 1997 and 2004, estimated at each percentile. ${ }^{13}$ Comparing the two figures, we observe opposing trends: while TR-progressivity is higher in 2004 for all quantiles above $p=0.25$, IR-progressivity is higher in 1997, for all $p<0.92$.

\footnotetext{
${ }^{10} \mathrm{DA}=k^{*} \mathrm{BA}$, where $k$ is the so-called 'dependent allowance factor'. The value of $k$ depends on the number of children and other dependent members of the family.

${ }_{11}$ Dividends make about $2 \%$ of total pre-tax income in 2004 , belonging exclusively to $10 \%$ top income-earners.

12 These micro data were compiled with the permission, help and support of the Tax Administration.

${ }^{13}$ Priority in presentation of results is given to the reduced sample (without pensioners), but a short comparison with the results obtained for the full sample is given at the end of this section.
} 
Figure 2 TR-progressivity and IR-progressivity by percentile
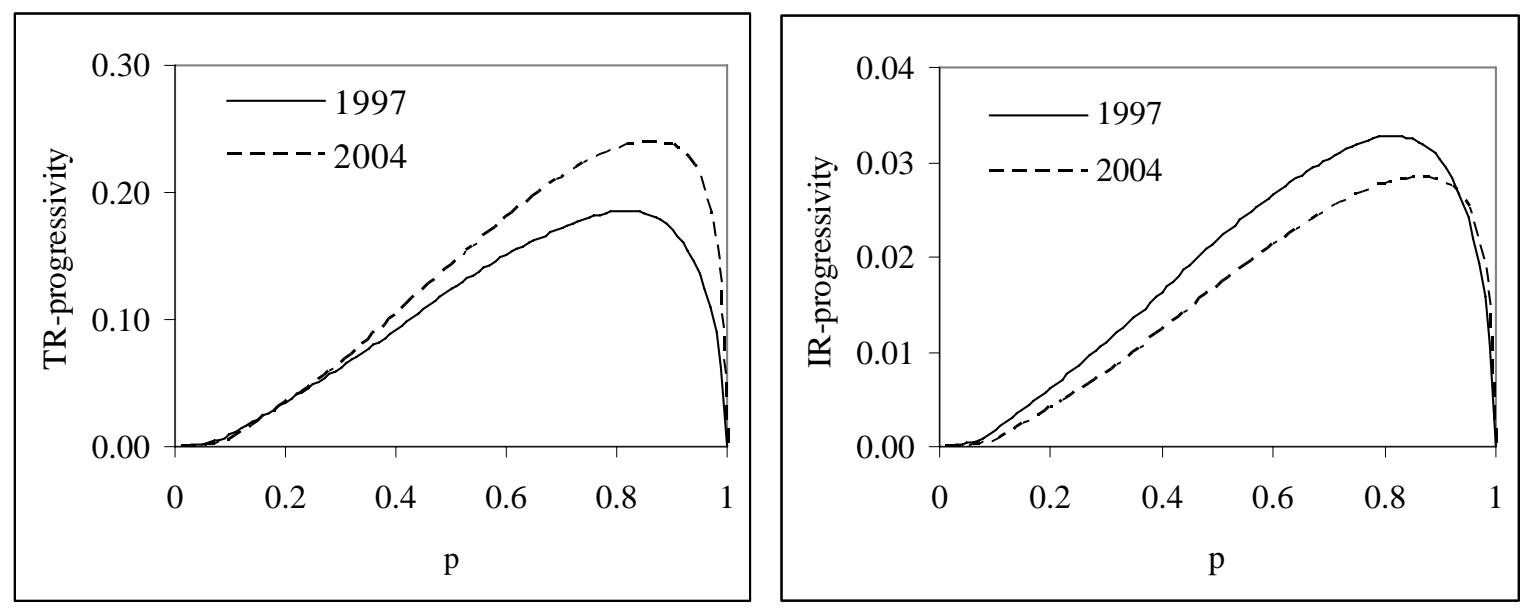

What do the progressivity curves for 1997 and 2004 tell us? In the case of TR-progressivity, if the tax were proportional, the progressivity curve would coincide with the $x$-axis, because each quantile's share in total tax would be equal to its share in pre-tax income. However, when the tax is progressive, the progressivity curve lies above the $x$-axis. In 1997 , for example, TR-progressivity at $p=0.8$ is equal to 0.187 . If the share of the poorest $80 \%$ taxpayers in total pre-tax income were $s \%$, under the proportional system they would pay $s \%$ of total tax; instead, they pay $(s-18.7) \%$ of total tax. Progressivity elements of the PIT system thus shifted $18.7 \%$ of the total PIT burden from the poorest $80 \%$ taxpayers onto the shoulders of the richest $20 \% .{ }^{14}$ The difference between 2004 and 1997 TR-progressivity equals, for example, 0.093 at $p=0.95$. It means that in 2004 the poorest $95 \%$ taxpayers shifted $9.3 \%$ of total PIT (of that year) more than in 1997 to the richest 5\%. On the other hand, IR-progressivity tells us how a departure from proportionality in taxation affects distribution of post-tax income. Again, if tax is progressive, the IR-progressivity curve will lie above the $x$-axis. For example, in 1997 (2004), IRprogressivity at $p=0.5$ amounted to $0.021(0.017)$. This means that the poorest half of taxpayers receive $2.1 \%(1.7 \%)$ more total post-tax income than they would receive under proportional taxation.

As equations (3a) and (3b) show, the two measures of progressivity are connected through the average tax rate. Increased concentration of taxes compared to pre-tax income (measured by TR-progressivity) could not compensate for a large decrease of the average tax rate over the period and bring the redistributive effect (measured by IR-progressivity) in 2004 to the level from 1997. The average tax rate, as can be seen from Table $2^{15}$, fell by one third over the period. The reasons are twofold; one is the declining share of the tax base in pre-tax income, due to increasing allowances and deductions, and the other, the declining tax-to-base ratio that stems from changes in marginal tax rates and definitions of tax brackets (see further for more details).

\footnotetext{
${ }^{14}$ Quantile $p^{*}$, at which TR-progressivity reaches the maximum, divides the taxpayers into two groups: those whose rank is $p<p^{*}$ pay less than the average tax rate, and those whose rank is $p>p^{*}$ pay more than the average tax rate. The value of $p^{*}$ increased from 0.82 in 1997 to 0.86 in 2004 .

${ }^{15}$ Appendix $C$ summarizes basic descriptive statistics of income, allowances and tax.
} 
Table 2 PIT elements - shares in pre-tax income and concentrations

\begin{tabular}{|c|c|c|c|c|}
\hline & \multicolumn{2}{|c|}{1997} & \multicolumn{2}{|c|}{2004} \\
\hline & Whole sample & $\begin{array}{l}\text { Sample without } \\
\text { pensioners }\end{array}$ & Whole sample & $\begin{array}{l}\text { Sample without } \\
\text { pensioners }\end{array}$ \\
\hline \multicolumn{5}{|c|}{ Share in pre-tax income } \\
\hline allowance (a) & 46.1 & 36.9 & 54.3 & 44.3 \\
\hline deductions (d) & 0.4 & 0.3 & 5.1 & 6.2 \\
\hline tax credits (c) & & & 0.0 & 0.0 \\
\hline tax base $(b)$ & 53.5 & 62.7 & 40.6 & 49.5 \\
\hline net tax $(t)$ & 12.3 & 14.8 & 8.2 & 10.2 \\
\hline$t / b$ & 23.0 & 23.6 & 20.1 & 20.6 \\
\hline \multicolumn{5}{|c|}{ Gini/concentration coefficients ${ }^{a}$} \\
\hline pre-tax income $\left(G_{x}\right)$ & 0.440 & 0.414 & 0.454 & 0.429 \\
\hline post-tax income $\left(\mathrm{G}_{\mathrm{N}}\right)$ & 0.402 & 0.378 & 0.424 & 0.398 \\
\hline allowance $\left(C_{A}\right)$ & 0.160 & 0.154 & 0.220 & 0.198 \\
\hline deductions $\left(C_{D}\right)$ & 0.578 & 0.494 & 0.634 & 0.499 \\
\hline tax base $\left(C_{B}\right)$ & 0.681 & 0.566 & 0.744 & 0.626 \\
\hline gross tax $\left(\mathrm{C}_{\mathrm{G}}\right)$ & 0.718 & 0.621 & 0.791 & 0.701 \\
\hline tax credit $\left(\mathrm{C}_{\mathrm{C}}\right)$ & & & 0.886 & 0.877 \\
\hline net tax $\left(\mathrm{C}_{\mathrm{T}}\right)$ & 0.718 & 0.621 & 0.791 & 0.701 \\
\hline
\end{tabular}

${ }^{a}$ These are regular Gini and concentration coefficients; they are equivalent to S-Gini indices of inequality and concentration for $v=2$.

Table 3 shows the global S-indices of IR- and TR-progressivity obtained for $v$-values ranging from 1.1 to 5. For all $v \geq 1.5$, IR-progressivity dominates in 1997, and for all $v$ TR-progressivity is larger in 2004. IR-progressivity is higher in 2004 for $v=1.1$, but the difference is not significant at the $5 \%$ level $(\alpha=0.05) .^{16} 17$

Table 3 Indices of IR- and TR-progressivity

\begin{tabular}{|c|r|r|r|r|r|r|}
\hline \multirow{2}{*}{$v$} & \multicolumn{3}{|c|}{$\pi^{I R}(v)$} & \multicolumn{3}{|c|}{$\pi^{T R}(v)$} \\
\cline { 2 - 7 } & 1997 & 2004 & $\begin{array}{r}\text { difference } \\
(2004-1997)\end{array}$ & 1997 & 2004 & $\begin{array}{r}\text { difference }^{\mathrm{a}} \\
(2004-1997)\end{array}$ \\
\hline 1.1 & 0.0101 & 0.0105 & 0.0004 & 0.0585 & 0.0925 & $0.0340^{*}$ \\
\hline 1.5 & 0.0294 & 0.0271 & $-0.0023^{*}$ & 0.1695 & 0.2397 & $0.0702^{\star}$ \\
\hline 2.0 & 0.0361 & 0.0309 & $-0.0052^{*}$ & 0.2082 & 0.2726 & $0.0644^{*}$ \\
\hline 3.0 & 0.0370 & 0.0291 & $-0.0079^{*}$ & 0.2134 & 0.2567 & $0.0433^{*}$ \\
\hline 5.0 & 0.0319 & 0.0227 & $-0.0092^{*}$ & 0.1838 & 0.2004 & $0.0166^{*}$ \\
\hline
\end{tabular}

${ }^{a}$ Differences significant at the $5 \%$ level $(\alpha=0.05)$ are indicated by *.

\footnotetext{
${ }^{16}$ Bootstrap methodology described in Anderson et al (2003) is used to test statistical significance of the results. See Appendix $B$ for details about this.

${ }^{17}$ Reranking is relatively small in both year and reaches about $2 \%$ of IR-progressivity for a wide range of values of the ethical parameter.
} 
Table 4 presents S-Gini indices of pre-tax income, $G_{X}(v)$, which show that income inequality has unambiguously grown over the period. ${ }^{18}$ Blackorby-Donaldson indices show that the inequality-reducing power of the PIT system has weakened. These indices can be interpreted in the following way: for example, in 1997 the index for SDM with $v=2$ tells us that the actual system, due to its IRprogressivity, enabled $6.2 \%$ more (post-tax) welfare than an equal-yield proportional tax. We can see that this 'welfare premium from progression' rises as the ethical parameter is increased. Looked at from a different angle, for the same after-tax welfare, the progressive tax system enables a higher tax revenue than the proportional system. For example, ask the following question: If SDM with $v=2$ in 1997 wanted to apply proportionate tax and achieve same post-tax social welfare as the actual, what would be the tax rate? The answer is: (actual average tax rate minus $\pi^{T R P}(2) \cdot 100$ percent) $=14.8 \%$ $5.2 \%=9.6 \%$.

Table 4 Indices of welfare premium and tax revenue premium

\begin{tabular}{|c|r|r|r|r|r|r|}
\hline \multirow{2}{*}{$v$} & \multicolumn{2}{|c|}{$G_{X}(v)$} & \multicolumn{2}{|c|}{$\pi^{B D}(v)$} & \multicolumn{2}{|c|}{$\pi^{\text {TRP }}(v)$} \\
\cline { 2 - 7 } & 1997 & 2004 & 1997 & 2004 & 1997 & 2004 \\
\hline 1.1 & 0.0794 & 0.0853 & 0.0110 & 0.0115 & 0.0093 & 0.0103 \\
\hline 1.5 & 0.2784 & 0.2917 & 0.0407 & 0.0383 & 0.0347 & 0.0344 \\
\hline 2.0 & 0.4135 & 0.4286 & 0.0616 & 0.0541 & 0.0524 & 0.0486 \\
\hline 3.0 & 0.5593 & 0.5762 & 0.0840 & 0.0687 & 0.0715 & 0.0617 \\
\hline 5.0 & 0.6968 & 0.7154 & 0.1052 & 0.0798 & 0.0896 & 0.0716 \\
\hline
\end{tabular}

\subsection{Progressivity decomposition}

Figure 3 shows the decomposition of IR-progressivity across quantiles of the pre-tax income distribution. First to state something about general relationship between the various effects: the allowance effect is about 6-7 times more intensive than the rate effect on the median, but as we approach top quantiles the relative contributions of the allowance and rate effects converge to $50 \%$. The deductions effect is invisible in 1997, but had increased to negative $3 \%$ of overall IR-progressivity in 2004. Tax credit effect is negligible in 2004 due to its small share in pre-tax income, and therefore we ignore it in further analysis. Despite numerous changes in the PIT system during the period, its main redistributive patterns remained the same, with allowances as the strongest progressivity enhancing element, followed by the rate structure. However, as already mentioned above, its redistributive power has weakened. The following analysis tries to explain how different elements contributed to the declining redistributive effect.

\footnotetext{
${ }^{18}$ For more on income inequality in Croatia, see Nestić (2005) and Čok and Urban (2006).
} 
Figure 3 IR-progressivity decomposition by percentile

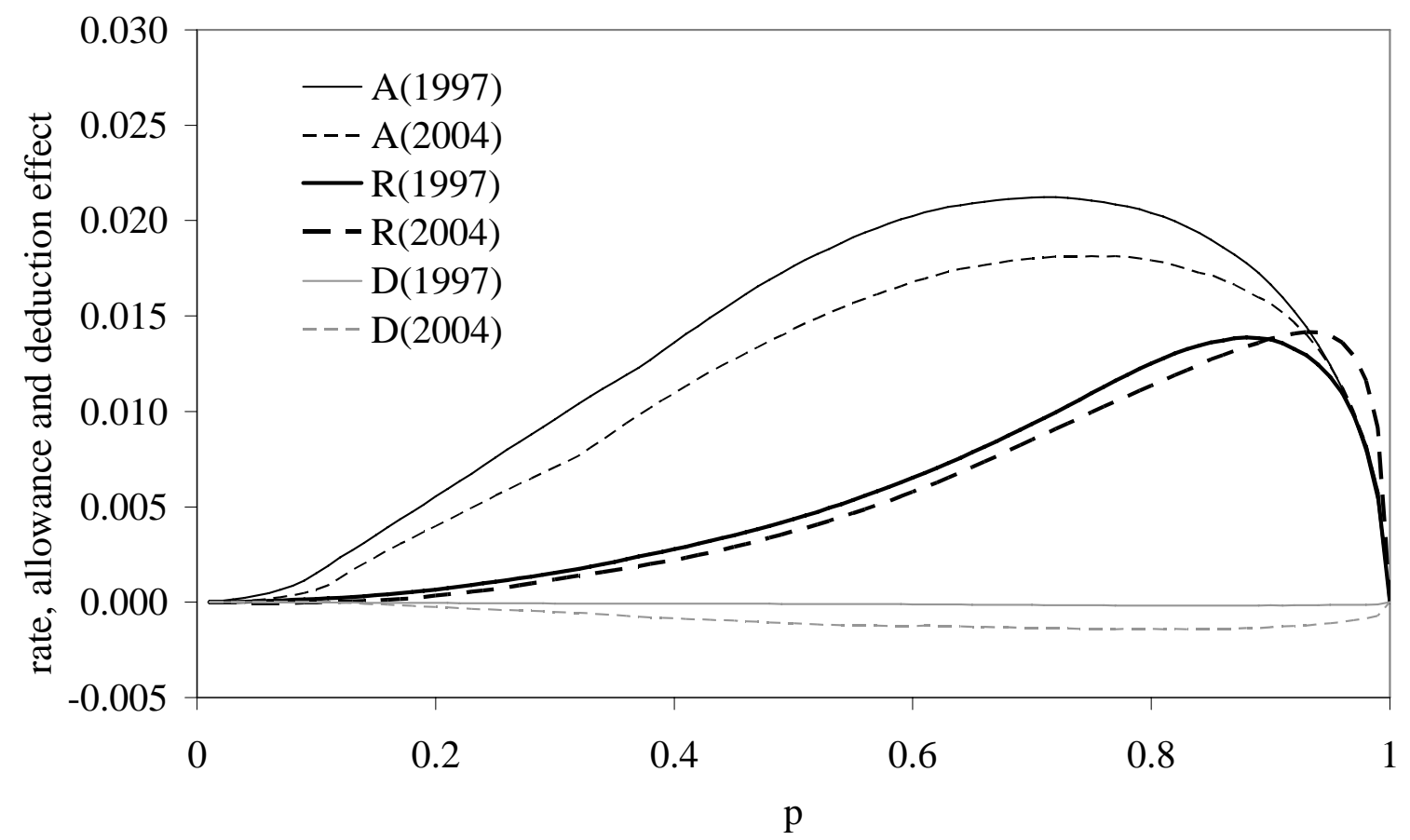

Note: quantile effects are defined in formula (9); $A$ - allowance effect; $R$ - rate effect; $D$ - deductions effect

Three main changes in Croatian PIT happened between 1997 and 2004: a) personal allowance was doubled (while mean pre-tax income grew by $65 \%$ ); b) rate structure became steeper with highest (lowest) marginal tax rate changed from $35 \%$ to $45 \%$ (20\% to $15 \%)$; c) a number of deductions were introduced, all of them being income-elastic (i.e. they are more concentrated than pre-tax income). All these changes had different impacts on concentration and relative magnitudes of allowances, deductions and net tax, and consequently, on IR-progressivity. Higher allowances and deductions eroded the tax base, which fell from $62.7 \%$ to $49.5 \%$ of pre-tax income, as can be seen in Table 2 , almost half of this drop being attributable to deductions. The decrease of the tax base could have been compensated by a corresponding rise of marginal tax rates, but this has not happened. Moreover, the opposite trend occurred: as Figure 4 shows, average tax rate as a function of the tax base (denoted as $u(B))$ is lower in 2004 for all amounts less than 325 thousand kuna. Only the $0.2 \%$ richest taxpayers have a tax base higher than this and although they contribute $5.4 \%$ of the total tax base, an increase of their marginal tax rate could not compensate for lower average rates at tax bases below 325 thousands kuna. As a final result, the average tax rate $(t)$ fell from 0.148 to 0.102 or by $31 \%$. 


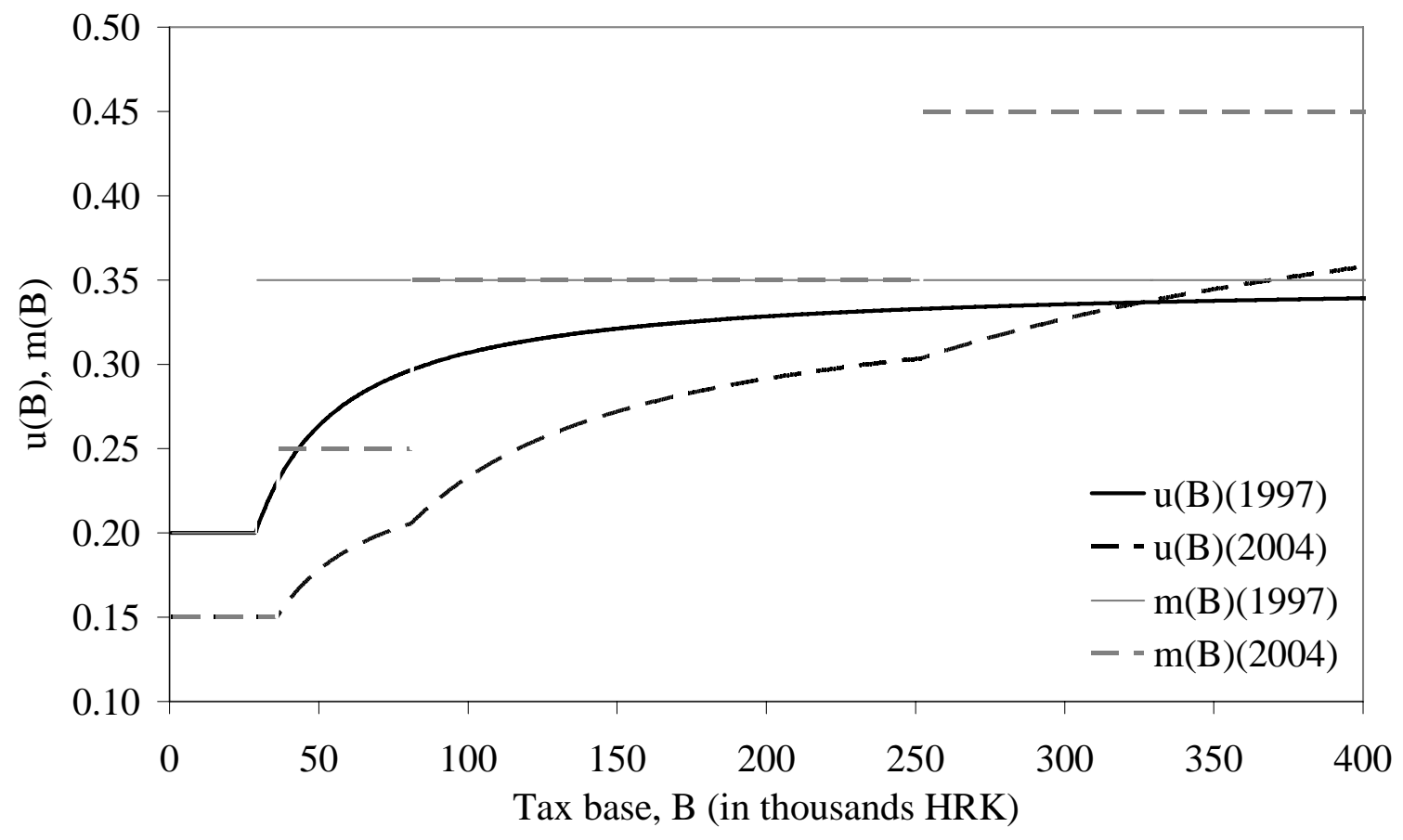

Notes: $u(B)=T / B ; m(B)=d T / d B$; where $T$ is tax liability and $B$ is tax base

Relaxation of the fall in IR-progressivity due to a large decrease of the average tax rate could have come from three sources: lower concentration of allowances, higher share of allowances in pre-tax income $(a)$, and more progressive (steeper) tax schedule ${ }^{19}$. The first two sources are actually conradictory: from Table 2 we can see that the concentration of allowances $\left(C_{A}\right)$ has increased, which is caused by a large increase of the 'nominal' amount of personal allowance: a larger number of people simply cannot use the whole amount to which they have right. ${ }^{20}$ In Figure 3 we see that the allowance effect in 1997 is smaller than in 2004 at all quantiles, and that the rate effect is smaller for all but the highest income ranks. However, both effects fell by only $12 \%$ on average across the pre-tax income quantiles, compared to a $31 \%$ fall in the average tax rate. Thus, the increased share of allowances in pre-tax income $(a)$ and the increased progressivity of rate structure did compensate for part of the IRprogressivity fall. Lastly, there is negative deductions effect that further prevents the PIT system in 2004 from achieving 1997 IR-progressivity.

We now turn to shares of allowance, rate structure, and deductions effects in S-indices of IRprogressivity, which are presented in Figure 5 for a wide range of $v$-values, and obtained for both reduced and full samples (denoted respectively as 'rs' and 'fs' in the figure). We shall concentrate first on the results for the reduced samples. Two main factors of progressivity, the allowances and rate structure, have opposite trends as the ethical parameter increases. The share of the allowance effect for both years is increasing in $v$ and at some point reaches the value 0.8 , meaning that $80 \%$ of

\footnotetext{
${ }^{19}$ Tax schedule in 2004 indeed obtains significantly greater elasticity for all values of tax base (except on small interval of 31,000-36,000 kuna, where elasticity was slightly greater in 1997).

${ }^{20}$ Suppose that persons $P$ and $Q$ have pre-tax incomes of $\$ 100$ and $\$ 200$. If 'nominal' allowance is set to $\$ 100$, then both persons fully use it and the allowance is absolutely equally distributed. But, if 'nominal' allowance is increased to $\$ 150$, then $P$ still uses $\$ 100$ and $Q$ uses $\$ 150$, and therefore concentration of allowances is increased.
} 
progressivity is attributed to allowances. On the other hand, the share of the rate effect in progressivity increases from 0.2 to 0.4 as we move to the left along the $x$-axis. To explain these trends we must remember that the majority of the rate effect is obtained at the upper quantiles of the distribution (Figure $3)$, to which S-indices with high values of $v$ give much less importance.

Why do we care about these shares estimated for a wide range of ethical parameter? For example, Wagstaff and van Doorslaer (2001) calculate the shares only for $v=2$ and compare the results for 15 countries. However, the choice of value $v=2$ is no less arbitrary and more self-evident than any other choice ${ }^{21}$ Here, in case of Croatia we could choose $v=3$ and conclude that the allowance effect is key element in achieving progressivity. Equally so, choosing $v=1.5$ we could well conclude that PIT is progressive due to the even mixture of allowance and rate effect. Therefore, Lambert (1999) suggests the use of S-Gini indices in international and intertemporal comparisons as a way in which "robustness of conclusions derived using the regular Gini-based [progressivity measures] can be tested".

Figure 5 Shares of allowance, rate structure and deductions effects in overall IR-progressivity, as functions of $v$

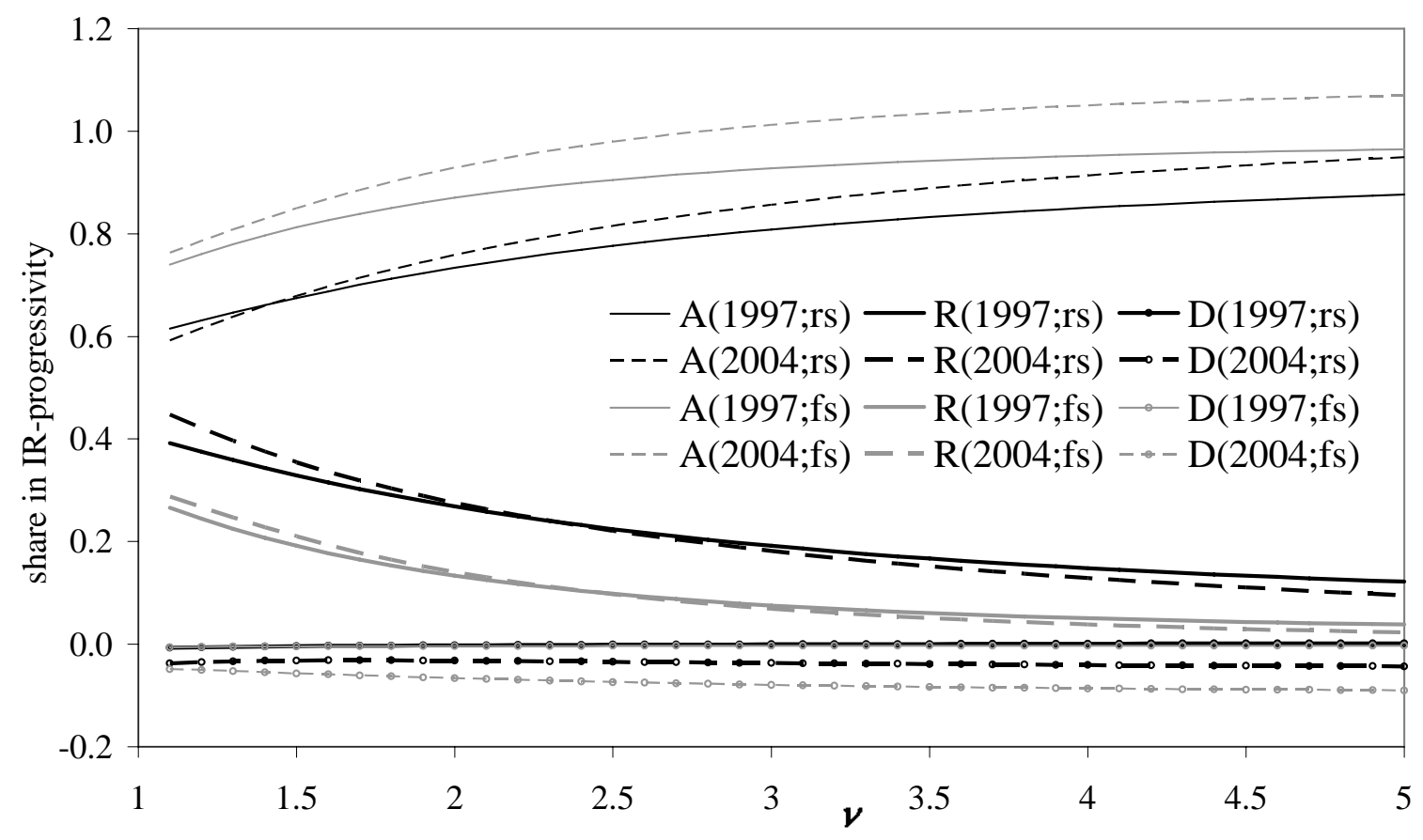

Note: 'rs'=reduced sample; 'fs'=full sample

Another factor that can lead to misleading comparisons is population coverage. Figure 5 reveals that the shares of the effects in total IR-progressivity are significantly different if the full sample (one that includes pensioners) is analyzed. Here, we see that the allowance effect is far larger, and at the expense of the rate effect, while the share of the deductions effect is about twice as big. The supremacy

\footnotetext{
${ }^{21}$ Duclos and Tabi (1995) limit their choice of $v$ to a maximum 4, based on the 'leaky bucket experiment', this leak reflecting "the feature that tax and benefit programmes often generate efficiency losses which are nevertheless tolerated because these programmes can enhance the equity of the income distribution making it less unequal".
} 
of the allowance effect is due to pensioners' high personal allowance, which results in only small percentage of pensioners actually facing a tax schedule.

\subsection{Further analysis: simulation}

From the findings above, we reach the conclusion that SDMs with different ethical considerations will value differently the contributions of PIT elements in achieving progressivity. Those with higher (lower) values of ethical parameter will attribute more relative importance to the allowance effect (rate effect).

One evident application of the knowledge about what makes a PIT progressive is related to tax reform. Wagstaff and van Doorslaer (2001) mention the case of an SDM who uses the rate structure to influence progressivity. If the current rate effect is low, then even a significant increase in the progressivity of the rate structure would not help to bring a desired increase in overall progressivity. Another interesting example is the introduction of a flat-rate PIT, accompanied by the abolition of all or many of the exemptions and deductions. Based on our findings in respect of the Croatian PIT, we are tempted to conclude that the single rate system could achieve much of (if not even more than) the existing progressivity as defined by our S-indices. However, there are certain restraints to such conclusions, which the following exercise will highlight.

Imagine that a current PIT system is replaced by a quite simple one with a single personal allowance, equal for all taxpayers, and with no other allowances or deductions. There is only one marginal rate, and the system has to be revenue-neutral. There is an unlimited set of combinations of allowance and marginal rate that would satisfy the given condition, but we set a second condition: that the system must be $\pi^{I R}(v)$-neutral. We call this alternative tax scheme "unique allowance-single rate" (henceforth UASR) system in what follows. Thus, the IR-progressivity of the simulated system must be the same as of the actual one, for the chosen $v$-value. It must be recalled that it is not the policy recommendation of this paper that policy makers should replace the actual system with this one; moreover, the modeled system is very simplistic (and rather unrealistic), but as such serves its main purpose, which is to offer a supplement to conclusions reached using progressivity decomposition formulas. ${ }^{22}$

Denote by $\eta$ the amount of nominal personal allowance for each taxpayer. ${ }^{23}$ The S-index of IRregressivity of the allowance achieved with $\eta$ is obtained by integrating in negative counterpart of $(4)^{24}$ :

$$
\rho_{A}^{\eta}(v)=\int_{0}^{1} \rho_{A}^{\eta}(p) \kappa(p) d p
$$

\footnotetext{
For example, the maximum tolerable leak of transferring $1 \$$ from the person whose individual rank is $p_{j}=2 / 3$ in the income distribution to person whose rank is $p_{i}=1 / 3$ amounts to 87.5 cents for SDM with $v=4$.

${ }^{22}$ Discussions about flat-rate PIT introduction in Croatia were rather sporadic. However, this exercise might provide some insights for SDM in other countries that might be contemplating such a move, or have already established a flat-rate system.

${ }^{23}$ The allowance of taxpayer $i$ is thus $A_{i}=\eta$ if $X_{i} \geq \eta$ and $A_{i}=X_{i}$ if $X_{i}<\eta$.

${ }^{24}$ Remember that the "regressivity" of allowance is equal to negative progressivity of allowance, $\rho_{A}(p)=-\pi_{A}(p)$.
} 
Because there are no tax credits and deductions, and there is no rate structure either, the index of IRprogressivity of the flat-rate system, $\pi^{I R, F}(v)$ will be equal to the allowance effect. Thus, from (3a) and (18) we have that:

$$
\pi^{I R, F}(v)=\frac{t^{F}}{1-t^{F}} \rho_{A}^{\eta}(v)
$$

where $t^{F}$ is the average tax rate of the flat-rate system. Rearranging (19) and setting conditions $\pi^{I R, F}(v)=\pi^{I R, A}(v)$ and $t^{F}=t^{A}$, where $\pi^{I R, A}(v)$ and $t^{A}$ are respectively the IR-progressivity and average tax rate of the actual system, we obtain (20), which calculates the index of regressivity of allowances, achieved with nominal allowance $\eta^{*}$, at which the IR-progressivities of the flat and actual systems are the same:

$$
\rho_{A}^{\eta^{*}}(v)=\frac{1-t^{A}}{t^{A}} \pi^{I R, A}(v)
$$

The simulation goes as follows: using the distribution of pre-tax incomes, we calculate values of $\rho_{A}^{\eta}(v)$ for a wide range of $\eta$-values and we then look for $\rho_{A}^{\eta^{*}}(v)$. The needed single tax rate $\varphi^{*}$ is then obtained as $\varphi^{*}=t^{A} / b^{\eta^{*}}$, where $b^{\eta^{*}}$ is ratio of the tax base to total pre-tax income when $\eta=\eta^{*}$.

The simulation is done for the pre-tax income distribution of 2004, for several values of the ethical parameter. The rows of Table 5 present the unique allowance and single tax rate required for three IRprogressivity neutral UASR models, at $v=1.5, v=2$ and $v=3$, called M1-M3 respectively. For example, model M3 equalizes the IR-progressivity of the UASR system at $v=3$ with the IRprogressivity of the actual system obtained for the same ethical parameter.

Table 5 UASR models for 2004

\begin{tabular}{|c|c|r|r|r|r|r|}
\hline Model & Condition & $\begin{array}{r}\text { Unique } \\
\text { allowance } \\
\left(\alpha^{*}\right)\end{array}$ & $\begin{array}{r}\text { Flat tax } \\
\text { rate } \\
\left(\varphi^{*}\right)\end{array}$ & $\begin{array}{r}\text { IR-progress. } \\
\pi^{I R}(1.5)\end{array}$ & $\begin{array}{r}\text { IR-progress. } \\
\pi^{I R}(2)\end{array}$ & $\begin{array}{r}\text { IR-progress. } \\
\pi^{I R}(3)\end{array}$ \\
\hline $\mathrm{M} 1$ & $\pi^{I R, F}(1.5)=\pi^{I R, A}(1.5)$ & 31,590 & 0.2277 & 0.0271 & 0.0345 & 0.0361 \\
\hline $\mathrm{M} 2$ & $\pi^{I R, F}(2)=\pi^{I R, A}(2)$ & 27,960 & 0.2058 & 0.0238 & 0.0309 & 0.0333 \\
\hline $\mathrm{M} 3$ & $\pi^{I R, F}(3)=\pi^{I R, A}(3)$ & 23,480 & 0.1816 & 0.0195 & 0.0259 & 0.0291 \\
\hline
\end{tabular}

Table 5 shows that the models with a lower value of the ethical parameter require a higher allowance (and, naturally, a higher single tax rate), and achieve unambiguously higher IR-progressivity than those with a higher value of the ethical parameter, as can also be seen from Figure 6. At the first sight, the conclusion that the SDM with lower value of $v$ will ask for more progressive tax than the SDM with higher $v$ seems to be contradictory. We have seen earlier that all SDM's with $v>1$ are 'progressivity lovers' in sense that for all of them progressive tax delivers a welfare premium compared to an equalyield proportionate tax; they only differ in degree of this feeling, in the sense that the welfare premium 
increases in $v$. The case shown in Table 5 is no exception: $\pi^{I R}(3)>\pi^{I R}(2)>\pi^{I R}(1.5)$ for all three models, M1-M3. The reason for an SDM with lower value $v$ asking for relatively more progressivity in a simulated system lies in his perception of the progressivity of the actual system. We have seen that an SDM with low (high) values of $v$ attributes greater relative significance to progressivity obtained at higher (lower) quantiles of pre-tax distribution. The actual system achieves most of its progressivity at the highest quantiles, largely thanks to progressive rate structure that, of course, does not exist in UASR models. The only way available way for an SDM with low $v$ to compensate for lack of progressive rates is to increase the personal allowance, and thus achieve more elastic tax function.

Figure 6 Progressivity of actual system and simulated UASR system in 2004 by percentile

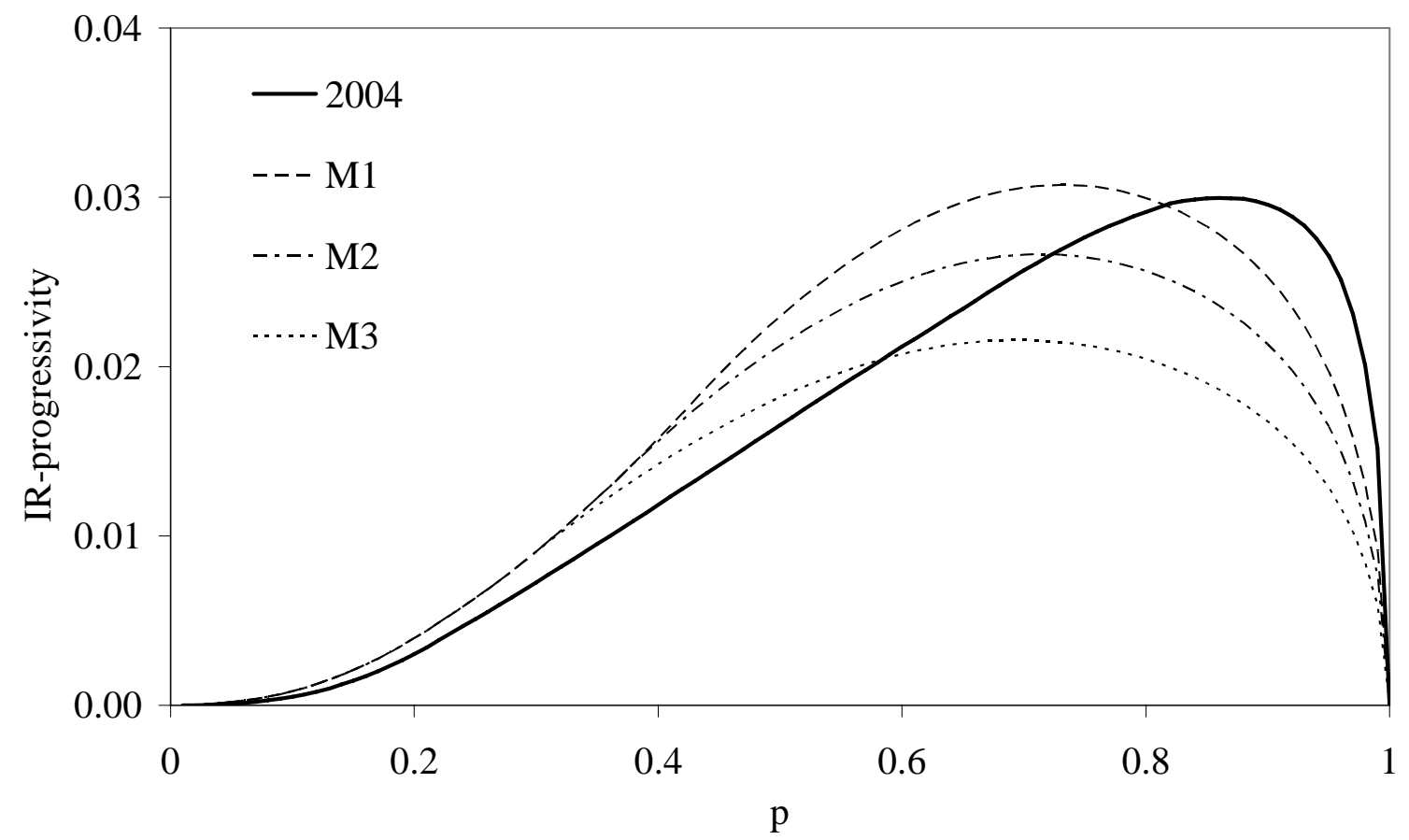

Lambert (2001) says that "popular analysis [of income tax reform] begins, and often ends, by identifying the pattern of gainers and losers when taxes are changed" ${ }^{25}$ Here we end with the analysis of change in tax burdens caused by three UASR models. Figure 7 presents changes in the average tax rate that would occur under these alternative tax systems compared to the actual system, with positive changes representing an increase in tax burden and vice versa. Again we face a contradictory result: due to larger personal allowance, the model M1, based on lowest $v$, creates tax cuts for the largest number of lower-income people and the smallest number of people with highest incomes (and smallest cuts for this group), among all three models.

\footnotetext{
${ }^{25}$ One such analysis is provided for current PIT system in Croatia by Urban (2006).
} 
Figure 7 Difference between the average tax rate for simulated UASR system and actual system in 2004 by percentile

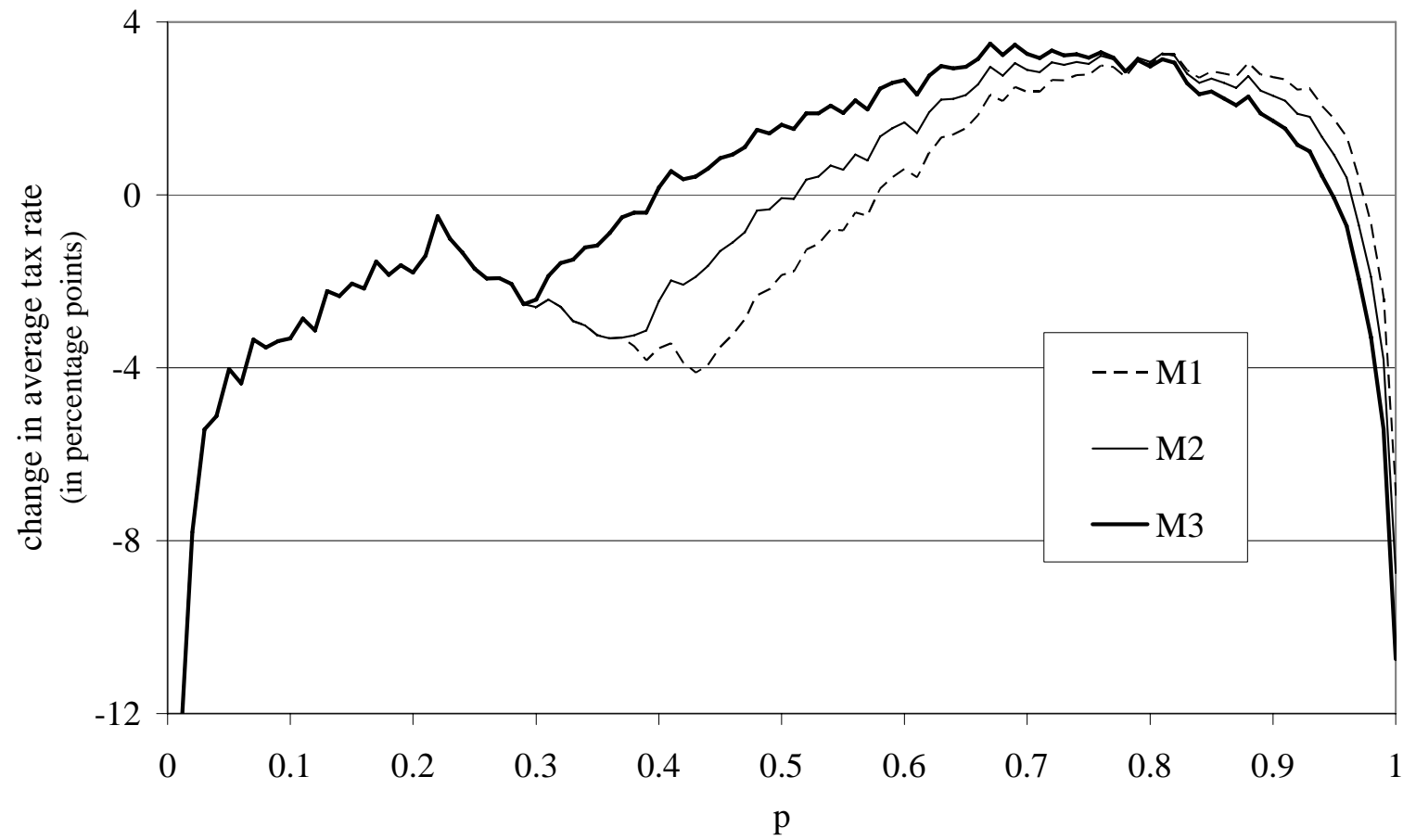

\section{CONCLUSION}

This paper analyzed various redistributional aspects of Croatian personal income tax from 1997 to 2004. Progressivity was decomposed using the methodology proposed by Pfähler (1990) and further elaborated by Lambert (2001). The breakdowns reveal how different elements of the PIT system, that is, the rate structure, allowances, deductions and tax credits, contribute to the achievement of overall progressivity. It is shown that the patterns of progressivity, and the effects of the elements which cause it, vary over the quantiles of the pre-tax income distribution. Quantile analysis thus has an advantage over scalar measures, such as the standard Gini-based measures of income inequality (Gini coefficient), and of progressivity (Reynolds-Smolensky and Kakwani indices). However, in this paper scalar measures are also used, so-called S-indices, which have been purpose-designed in terms of single parameter Gini and concentration indices, where the parameter expresses the SDM's ethical judgments. For different choices of the ethical parameter underpinning the S-indices, comparison of results obtained for different time periods (countries) will bring different results. Also, the conclusions about the relative contributions of PIT elements to progressivity are sensitive to the coverage of population that is analyzed.

The redistributive power of Croatian PIT fell over the period, thanks to the lower average tax rate, and in spite of the increased concentration of taxes as compared to the inequality of pre-tax income. On average, the largest share of progressivity can be attributed to allowances, while the rate structure is more important at the upper quantiles. Deductions, as in other countries, have a negative contribution to progressivity. Tax credits are a negligible element of the Croatian personal income tax system. 
The applicability of this kind of analysis was recognized by Wagstaff and van Doorslaer (2001), who calculated and compared progressivity decompositions of PIT systems in 15 OECD countries. For a country planning a tax reform, it is important to know how progressivity is achieved in the current system. Based on that, some recommendations can be given on possible paths for reform. It is shown that a simple flat-rate revenue-neutral system could preserve progressivity. Parameters of this system, allowance and single rate, would depend upon the ethical stance of the SDMs: those relatively less (more) favorably inclined to the lower tail of the pre-tax income distribution will choose a higher (lower) allowance and a higher (lower) single tax rate. 


\section{REFERENCES}

Anderson, J. E., Ghosh Roy, A. and Shoemaker, P. A., 2003. "Confidence Intervals for the Suits Index", National Tax Journal, 56 (1), 81-91.

Blackorby, C. and Donaldson, D., 1984. "Ethical social index numbers and the measurement of effective tax/benefit progressivity". Canadian Journal of Economics, 17 (4), 683-694.

Čok, M. and Urban, I., 2006. "Distribution of income and taxes in Slovenia and Croatia". Working paper, No. 180. Ljubljana: Faculty of Economics.

Donaldson, D. and Weymark, J. A., 1980. "A Single Parameter Generalization of the Gini Indices of Inequality". Journal of Economic Theory, 22, 67-86.

Duclos, J.-Y. and Araar, A., 2006. "Poverty and Equity Measurement, Policy and Estimation with DAD" [online]. Available from: [http://132.203.59.36/DAD/manual/theory.htm].

Duclos, J.-Y., and Tabi, M., 1995. "Linear Inequality Measures and the Redistribution of Income". Working paper, No. 9613. Quebec: Laval University.

Duclos, J.-Y., Jalbert, V. and Araar, A., 2003. "Classical horizontal inequity and reranking: an integrated approach". Research on Economic Inequality, 10, 65-100.

Kakwani, N. C., 1977a. "Applications of Lorenz Curves in Economic Analysis". Econometrica, 45 (3), 719-728.

Kakwani, N. C., 1977b. "Measurement of Progressivity: An International Comparison". The Economic Journal, 87 (345), 71-80.

Lambert, P. J., 1999. "Redistributional effects of progressive income taxes" in: J. Silber, ed. Handbook on Income Inequality Measurement. Norwell, MA: Kluwer Academic Publishing, 485-509.

Lambert, P. J., 2001. The Distribution and Redistribution of Income. Manchester: Manchester University Press.

Mehran, F., 1976. "Linear measures of income inequality". Econometrica, 44 (4), 805-809.

Nestić, D., 2005. "Income distribution in Croatia: what do the household budget survey data tell us?" [online]. Financial Theory and Practice". Financijska teorija i praksa, 29 (1), 39-53. Available from:: [http://www.ijf.hr/eng/FTP/2005/1/nestic.pdf].

Pfähler, W., 1987. "Redistributive effects of tax progressivity: evaluating a general class of aggregate measures". Public Finance/Finances Publiques, 42 (1), 1-31.

Pfähler, W., 1990. "Redistributive Effect of Income Taxation: Decomposing Tax Base and Tax Rates Effects". Bulletin of Economic Research, 42 (2), 121-29.

Urban, I., 2006. "A single rate of personal income tax: the impact on the distribution of the tax burden" [online]. Newsletter, No. 24. Zagreb: Institute of Public Finance. Available from: [http://www.ijf.hr/eng/newsletter/24.pdf].

Wagstaff, A. and van Doorslaer, E., 2001. "What Makes the Personal Income Tax Progressive? A Comparative Analysis of Fifteen OECD Countries". International Tax and Public Finance, 8 (3), 299315. 


\section{APPENDIX}

\section{A. S-Gini social welfare function}

S-Gini social welfare function aggregates individual incomes in the following way:

$$
W(v)=\int_{0}^{1} Q(p) \omega(p, v) d p
$$

where $\omega(p, v)=v(1-p)^{v-1}$ is a weighting scheme with single-parameter $v$. Figure A1 illustrates $\omega(p, v)$ for several values of the ethical parameter $v$. For $v=1$ the weights are equal to 1 for all individuals, and in this case welfare is identical to per capita income, a common aggregate measure of society's living standard. For $v>1$, weights are decreasing in $p$, such that $\omega(p=0, v)=v$ and $\omega(p=1, v)=0$. Also observe that $\int_{0}^{1} \omega(p, v) d p=1$, i.e. the weights sum up to 1 . As Duclos and Araar (2006) show, the S-Gini social welfare function can also be expressed using Lorenz curve and weighting scheme $\kappa(p ; \rho)$, where $\mu$ is the average actual income:

$$
W(v)=\mu \int_{0}^{1} L(p) \kappa(p, v) d p
$$

Figure A1 Weights for S-Gini social welfare function

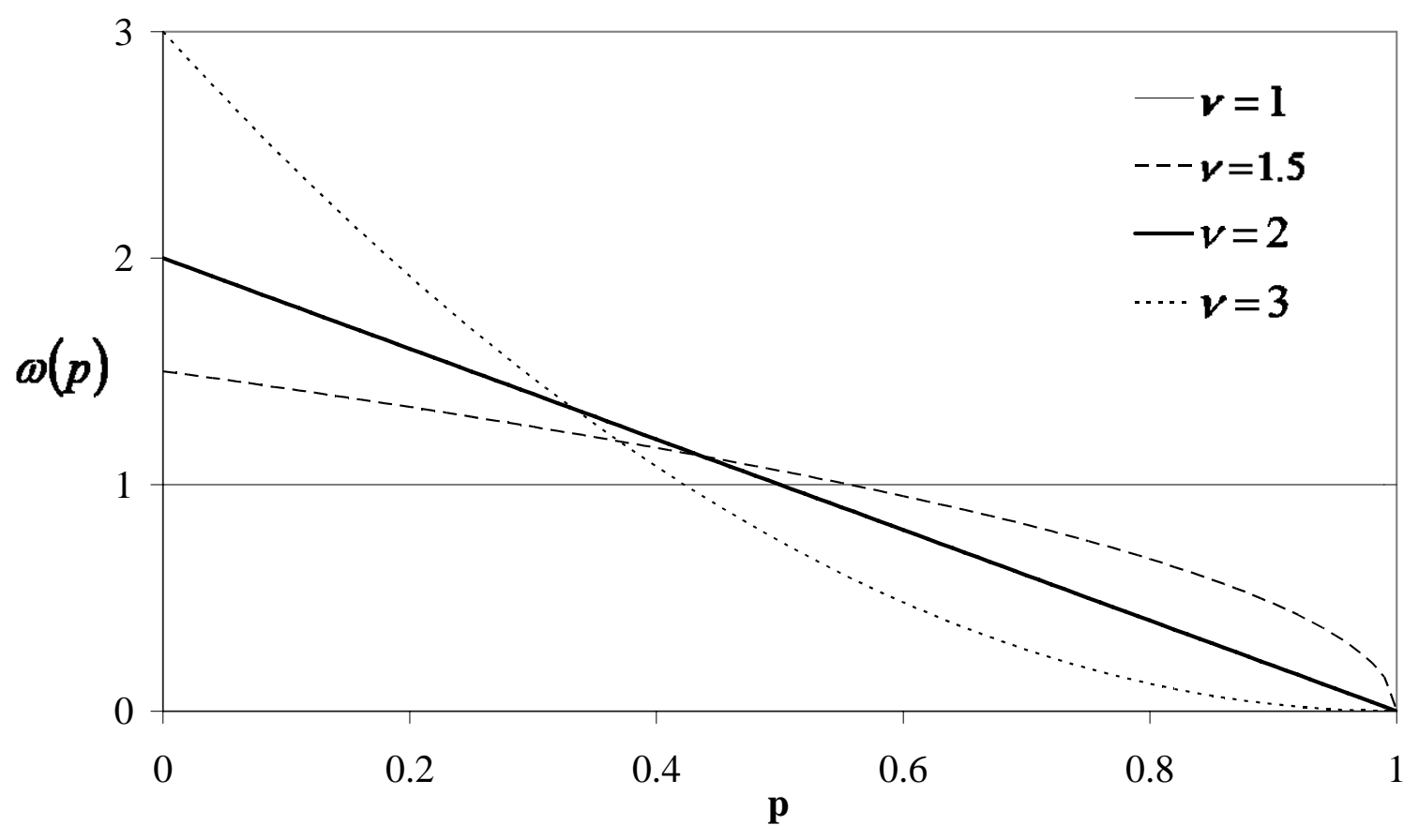

Suppose that an SDM is aiming to achieve a purely egalitarian society (i.e. one in which all people have the same income). This would be done by progressive taxation of rich and transfers to poor. In this process, people would certainly lose part of their incentive to earn income and total income would fall 
below the current. Let $\xi$ be the income of each individual in an egalitarian society in which the welfare would be the same as actual (so-called equally distributed equivalent, EDE), and $\mu-\xi$ is the loss of income per capita due to loss of earning incentives. What part of the total income would an SDM be ready to sacrifice to achieve his goal? The answer is given by index of income inequality, $I$ :

$$
I=\frac{\mu-\xi}{\mu}=1-\frac{\xi}{\mu}
$$

In our specific case of S-Gini social welfare function, we have that $\xi=W(v)$ and $I=G(v)$, where $G(v)$ is the S-Gini index of income inequality, defined in section 2:

$$
G(v)=1-\frac{W(v)}{\mu}
$$

\section{B. Statistical inference}

As the values of all indicators are estimated from samples, we need to check their statistical significance. Anderson et al (2003) used the following bootstrap sampling procedure to estimate confidence intervals for the Suits index. There are three stages of sampling; we name the resulting samples the $1^{\text {st }}, 2^{\text {nd }}$ and $3^{\text {rd }}$ stage samples. The first stage is the drawing of a representative sample from the population; we assume this has already been done. Using the data from the original or $1^{\text {st }}$ stage sample, estimates of various indicators are obtained. Call $\hat{V}^{1}$ and $\hat{V}^{2}$ the estimates of one such indicator in periods 1 and 2 , and $\hat{D}=\hat{V}^{1}-\hat{V}^{2}$ their difference. From the original sample, a certain number $N$ of $2^{\text {nd }}$ stage samples, of the same size as the original sample, are drawn randomly with replacement. Vectors $v^{1^{*}}=\left[v_{1}^{1^{*}}, \ldots, v_{N}^{1^{*}}\right]$ and $v^{2^{*}}=\left[v_{1}^{2^{*}}, \ldots, v_{N}^{2^{*}}\right]$ contain bootstrap replications of the desired measure for each of these $N$ samples in periods 1 and 2 . Let the difference between the values in the two periods be $d^{*}=v^{1^{*}}-v^{2^{*}}$. The bootstrap standard error of $\hat{D}$ is obtained as:

$$
\hat{\sigma}=\sqrt{\frac{1}{N-1} \sum_{i=1}^{N}\left(d_{i}^{*}-\bar{d}^{*}\right)^{2}}
$$

where $\bar{d}^{*}=\frac{1}{N} \sum_{j=1}^{N} d_{j}^{*}$. In the third stage, from each of the $N$ samples, $M$ new samples are drawn randomly with replacement, all of the same size as the original sample. Let $v_{i}^{1 * *}=\left[v_{i, 1}^{1 * *}, \ldots, v_{i, M}^{1 * *}\right]$ and $v_{i}^{2^{* *}}=\left[v_{i, 1}^{2 * *}, \ldots, v_{i, M}^{2 * *}\right]$ be the vectors of $\mathrm{M}$ bootstrap replications of the desired measure obtained, for samples drawn from ith $2^{\text {nd }}$ stage sample, in periods 1 and 2 , and let $d_{i}^{* *}=v_{i}^{1^{* *}}-v_{i}^{2 * *}=\left[d_{i, 1}^{* *}, \ldots, d_{i, M}^{2 * *}\right]$ be their difference. Then the bootstrap standard error for each of the $2^{\text {nd }}$ stage samples $(i=1 \ldots N)$ is equal to: 


$$
\hat{\sigma}_{i}^{*}=\sqrt{\frac{1}{M-1} \sum_{j=1}^{M}\left(d_{i, j}^{* *}-\bar{d}_{i}^{* *}\right)^{2}}
$$

where $\bar{d}_{i}^{* *}=\frac{1}{M} \sum_{j=1}^{M} d_{i, j}^{* *}$. The bootstrap t-statistic for each of the $2^{\text {nd }}$ stage samples is equal to $t_{i}=\left(d_{i}^{*}-\hat{D}\right) / \hat{\sigma}_{i}^{*}$. Let $t^{\alpha}$ and $t^{1-\alpha}$ be the $\alpha$ th and $(1-\alpha)$ th quantiles of the vector $t=\left[t_{1}, \mathrm{~K}, t_{N}\right]$. Then the $100(1-\alpha)$ percent confidence interval for $D$ is given by $\left[\hat{D}-t^{1-\alpha} \hat{\sigma}, \hat{D}-t^{\alpha} \hat{\sigma}\right]$. The null hypothesis $H_{0}: D=0$ can be rejected in favor of $H_{1}: D \neq 0$ only if lower and upper bound of the confidence interval both have the same sign. Note that the methodology requires that $N$ be at least 1,000 and $M$ at least 25 .

\section{Descriptive statistics of income, allowances and tax}

\begin{tabular}{|c|c|c|c|c|}
\hline & \multicolumn{2}{|c|}{1997} & \multicolumn{2}{|c|}{2004} \\
\hline & Whole sample & $\begin{array}{l}\text { Sample without } \\
\text { pensioners }\end{array}$ & Whole sample & $\begin{array}{l}\text { Sample without } \\
\text { pensioners }\end{array}$ \\
\hline Total pre-tax income* & 49,689 & 40,129 & 96,957 & 70,931 \\
\hline Wages and salaries & 35,065 & 35,065 & 63,003 & 63,003 \\
\hline Pensions & 9,007 & 0 & 23,209 & 0 \\
\hline Self-employment income & 3,150 & 3,105 & 5,035 & 4,903 \\
\hline $\begin{array}{l}\text { Income from part-time and } \\
\text { contractual work }\end{array}$ & 1,875 & 1,549 & 2,461 & 2,048 \\
\hline Rental income & 592 & 417 & 1,624 & 1,051 \\
\hline Dividends & 0 & 0 & 1,722 & 0 \\
\hline PIT & 6,101 & 5,938 & 7,916 & 7,219 \\
\hline \multicolumn{5}{|l|}{ Pre-tax income ${ }^{* *}$} \\
\hline mean & 24,226 & 29,269 & 37,294 & 45,685 \\
\hline standard deviation & 24,773 & 27,722 & 52,616 & 51,428 \\
\hline 25th percentile & 10,276 & 13,733 & 15,605 & 20,451 \\
\hline median & 17,711 & 23,932 & 27,061 & 36,635 \\
\hline 75th percentile & 31,498 & 37,446 & 47,405 & 58,929 \\
\hline \multicolumn{5}{|l|}{ Post-tax income } \\
\hline mean & 21,251 & 24,938 & 34,249 & 41,035 \\
\hline standard deviation & 18,513 & 20,291 & 41,773 & 38,693 \\
\hline 25th percentile & 10,106 & 13,012 & 15,520 & 20,098 \\
\hline median & 16,867 & 21,616 & 26,510 & 34,782 \\
\hline 75th percentile & 27,989 & 32,559 & 44,654 & 54,249 \\
\hline \multicolumn{5}{|l|}{ Personal allowance } \\
\hline mean & 11,178 & 10,805 & 20,258 & 20,230 \\
\hline standard deviation & 5,749 & 5,433 & 11,361 & 11,504 \\
\hline \multicolumn{5}{|l|}{ Other allowances } \\
\hline mean & 94 & 99 & 1,885 & 2,843 \\
\hline
\end{tabular}




\begin{tabular}{|c|c|c|c|c|}
\hline standard deviation & 1,583 & 1,834 & 10,865 & 13,732 \\
\hline \multicolumn{5}{|l|}{ Tax base } \\
\hline mean & 12,953 & 18,365 & 15,150 & 22,612 \\
\hline standard deviation & 23,382 & 26,000 & 46,882 & 43,597 \\
\hline \multicolumn{5}{|l|}{ Gross tax } \\
\hline mean & 94 & 99 & 3,050 & 4,654 \\
\hline standard deviation & 6,894 & 7,997 & 12,716 & 14,778 \\
\hline \multicolumn{5}{|l|}{ Tax credits } \\
\hline mean & 0 & 0 & 5 & 5 \\
\hline standard deviation & 0 & 0 & 230 & 270 \\
\hline \multicolumn{5}{|l|}{ Net tax } \\
\hline mean & 2,974 & 4,331 & 3,045 & 4,649 \\
\hline standard deviation & 6,894 & 7,997 & 12,709 & 14,770 \\
\hline
\end{tabular}

* million kuna; ** in kuna 


\section{INSTITUTE OF PUBLIC FINANCE - OCCASIONAL PAPER SERIES}

\begin{tabular}{|c|c|}
\hline No. 1 & $\begin{array}{l}\text { State Intervention for Growth Promotion in Market Economies } \\
\text { Marina Kesner Škreb, January } 1997\end{array}$ \\
\hline No. 2 & $\begin{array}{l}\text { Estimate of Revenues from the Value Added Tax in the Republic of Croatia } \\
\text { Danijela Kuliš and Žarko Miljenović, October } 1997\end{array}$ \\
\hline No. 3 & $\begin{array}{l}\text { The Unofficial Economy in Croatia: Causes, Size and Consequences } \\
\text { Ivo Bićanić and Katarina Ott, November } 1997\end{array}$ \\
\hline No. 4 & $\begin{array}{l}\text { Price Effects of VAT Introduction in Croatia } \\
\text { Martina Dalić, December } 1997\end{array}$ \\
\hline No. 5 & $\begin{array}{l}\text { Tax Administration Reform in Transition: The Case of Croatia } \\
\text { Katarina Ott, April } 1998\end{array}$ \\
\hline No. 6 & $\begin{array}{l}\text { The Present Sate of the Croatian Public Debt } \\
\text { Zoran Bubaš, December } 1998\end{array}$ \\
\hline No. 7 & $\begin{array}{l}\text { Public Investment in Croatia } \\
\text { Katarina Ott and Anto Bajo, March } 1999 .\end{array}$ \\
\hline No. 8 & $\begin{array}{l}\text { Welfare Policy and Social Transfers in Croatia } \\
\text { Predrag Bejaković and Alastair McAuley, July } 1999\end{array}$ \\
\hline No. 9 & $\begin{array}{l}\text { Is Unofficial Economy a Source of Corruption? } \\
\text { Vedran Šošić and Michael Faulend, November } 1999\end{array}$ \\
\hline No. 10 & $\begin{array}{l}\text { Banking Sector Problems: Causes, Resolutions and Consequences } \\
\text { Ljubinko Jankov, March } 2000\end{array}$ \\
\hline No. 11 & $\begin{array}{l}\text { Toward a Long - Term Strategy of Economic Development of Croatia: Where to Begin, What to Do, and } \\
\text { How to Do It? } \\
\text { Dubravko Mihaljek, June } 2001\end{array}$ \\
\hline No. 12 & $\begin{array}{l}\text { The Underground Economy in Croatia } \\
\text { Katarina Ott, March } 2002\end{array}$ \\
\hline No. 13 & $\begin{array}{l}\text { An Estimate of the Extent of Tax Evasion in Croatia } \\
\text { Sanja Madžarević Šujster, April } 2002\end{array}$ \\
\hline No. 14 & $\begin{array}{l}\text { Opportunism, Institutions and Moral Costs: The Socio - Cultural Dimension of the Underground } \\
\text { Economy in Croatia } 1995 \text { - } 1999 \\
\text { Aleksandar Štulhofer and Ivan Rimac, April } 2002\end{array}$ \\
\hline No. 15 & $\begin{array}{l}\text { Dollarisation and the Underground Economy: Accidental Partners? } \\
\text { Vedran Šošić and Michael Faulend, April } 2002\end{array}$ \\
\hline No. 16 & $\begin{array}{l}\text { Decentralization in the Republic of Croatia - A City Budget in the Period from } 1996 \text { to } 2000 \\
\text { Mihaela Pitarević, March } 2003\end{array}$ \\
\hline No. 17 & $\begin{array}{l}\text { Inequality in Croatia in the Period from } 1973 \text { to } 1998 \\
\text { Danijeli Nestić, April } 2003\end{array}$ \\
\hline
\end{tabular}




\begin{tabular}{|c|c|}
\hline No. 18 & $\begin{array}{l}\text { State Aid to Enterprises in Croatia in } 2001 \\
\text { Marina Kesner-Škreb, Ivana Pleše and Mia Mikić, October } 2003\end{array}$ \\
\hline No. 19 & $\begin{array}{l}\text { The Role of Parliament in the Budgetary Process - The Example of } \\
\text { the Croatian Parliament } \\
\text { Vjekoslav Bratić, October } 2004\end{array}$ \\
\hline No. 20 & $\begin{array}{l}\text { Local Government Unit Borrowing in Croatia: Opportunities and Constraints } \\
\text { Anto Bajo, October } 2004\end{array}$ \\
\hline No. 21 & $\begin{array}{l}\text { The Costs of Customs Compliance in Croatia in } 2001 \\
\text { Mihaela Bronić, November } 2004\end{array}$ \\
\hline No. 22 & $\begin{array}{l}\text { Tax Compliance Cost of Small Business in Croatia } \\
\text { Helena Blažić, November } 2004\end{array}$ \\
\hline No. 23 & $\begin{array}{l}\text { The Compliance Costs of Excise Duties in Croatia } \\
\text { Danijela Kuliš, November } 2004\end{array}$ \\
\hline No. 24 & $\begin{array}{l}\text { The Administrative Costs of Taxation and Customs Clearing in Croatia, 1999-2001 } \\
\text { Vjekoslav Bratić and Mihaela Bronić, November } 2004\end{array}$ \\
\hline No. 25 & $\begin{array}{l}\text { Fiscal Decentralization in Croatia: Problems of Fiscal Equalization } \\
\text { Anto Bajo and Mihaela Bronić, May } 2005\end{array}$ \\
\hline No. 26 & $\begin{array}{l}\text { Income Distribution in Croatia: What Do the Household Budget Survey Data Tell Us? } \\
\text { Danijel Nestić, June } 2005\end{array}$ \\
\hline No. 27 & $\begin{array}{l}\text { Impact of Foreign Direct Investment on Croatian Manufacturing Exports } \\
\text { Goran Vukšić, June } 2006\end{array}$ \\
\hline No. 28 & $\begin{array}{l}\text { Managing the Cash and Liquidity of the Croatian Budget } \\
\text { Anto Bajo, June } 2006\end{array}$ \\
\hline No. 29 & $\begin{array}{l}\text { The Quality of Governance and Economic Growth in Croatia } \\
\text { Marijana Bađun, June } 2006\end{array}$ \\
\hline No. 30 & $\begin{array}{l}\text { Can Capital Income Tax Improve Welfare in an Incomplete Market Economy with Labor-Leisure } \\
\text { Decision? } \\
\text { Danijela Medak Fell, December } 2006\end{array}$ \\
\hline No. 31 & $\begin{array}{l}\text { Tax Expenditure in Croatia: Personal Income, Corporate Income, Real Estate Transfers and Value } \\
\text { Added Tax } \\
\text { Vjekoslav Bratić, December } 2006\end{array}$ \\
\hline No. 32 & $\begin{array}{l}\text { Progressivity of Personal Income Tax in Croatia: Decomposition of Tax Base and Rate Effects } \\
\text { Ivica Urban, December } 2006\end{array}$ \\
\hline
\end{tabular}




\section{ABOUT THE INSTITUTE OF PUBLIC FINANCE}

The Institute of Public Finance (Zagreb, Croatia) founded in 1970, is a public institution dealing with research in the field of public sector economics, but also in applied and theoretical research on broader set of economic topics such as economic growth and development, role of institutions, transition to the market economy and EU integration. The empirical analysis is preferably related, but not limited, to experience of countries in Central and Eastern Europe and Southeast Europe.

\section{SELECTED LIST OF PUBLICATION (in English)}

\section{Serial publications}

- Financial Theory and Practice

- Occasional Paper Series

- Newsletter

\section{Books}

- Croatian Accession to the European Union: Facing the Challenges of Negotiations, editor Katarina Ott, 2005.

- The competitiveness of Croatia's human resources, editors Predrag Bejaković and Joseph Lowther, 2004.

- Croatian Accession to the European Union: Institutional Challenges, editor Katarina Ott, 2004.

- The Croatian Tax System, editor Mirjana Jerković, 2003.

- Croatian Accession to the European Union: Economic and Legal Challenges, editor Katarina Ott, 2003.

- The Citizen's Guide to Taxation, Marina Kesner-Škreb and Danijela Kuliš, 2001, (updated online).

- A Citizen's Guide to the Budget, editor Katarina Ott, 2000.

For further insight in our publications and ordering information please visit:

http://www.ijf.hr/eng/index.html. 